\title{
PENGENDALIAN INTERNAL DALAM PENGHIMPUNAN DANA NASABAH DI PD.BPR BANK SALATIGA
}

\author{
Sarah Wahidatun Niswah, Aprina Nugrahesthy Sulistya Hapsari \\ Fakultas Ekonomi dan Bisnis Universitas Kristen Satya Wacana \\ Email : 232015180@student.uksw.edu, esthy@staff.uksw.edu
}

\begin{abstract}
ABSTRAK
Tujuan dilakukannya penelitian ini adalah untuk melihat peran dari pihak auditor internal dalam menghadapi risiko dari aktivitas penghimpunan dana nasabah di PD.BPR Bank Salatiga apakah telah berjalan dengan efektif dan efisien. Pengawasan untuk aktivitas penghimpunan dana nasabah sangat penting dalam mencegah adanya risiko fraud yang mungkin saja bisa terjadi mulai dari pihak karyawan maupun dari pihak nasabah. Pengawasan yang dilakukan dalam mencegah adanya risiko fraud dimulai dari penilaian risiko yang dibuat oleh pihak auditor internal sehingga keterlibatan auditor dalam menilai risiko serta dalam menangani temuan yang terjadi dapat diselesaikan dan memberikan rekomendasi pihak terkait terhadap risiko yang ditemukan. Metode penelitian yang digunakan adalah metode diskriptif kualitatif dengan pendekatan fenomenologi di PD.BPR Bank Salatiga. Pemetaan analisis risiko akan disinkronkan dengan kejadian yang mungkin saja pernah terjadi sehingga diketahui peran dari pihak auditor internal dalam menilai dan menyelesaikan risiko yang terjadi. Dari analisis risiko dan temuan yang ada didaptkan bahwa peran pihak auditor internal dalam menilai dan menyelesaikan risiko yang terjadi sebatas sebagai pihak yang menangani ketika masalah yang terjadi tidak dapat diselesaikan oleh pihak terkait. Pengendalian internal yang dilakukan oleh pihak bank dalam menilai risiko yang bisa saja terjadi dikatakan cukup baik dalam menilai risiko yang muncul dan penanggulangan dari risiko yang muncul dapat terselesaikan.
\end{abstract}

Kata kunci : pengendalian internal, penghimpunan dana nasabah, penilaian risiko fraud

\section{ABSTRACT}

The purpose of this study is to look at the role of the internal auditors in dealing with risks from customer fundraising activities in PD.BPR Bank Salatiga has been running effectively and efficiently. Supervision of customer fund disbursement activities is very important in preventing the risk of fraud that may occur from the employee and the customer. Supervision carried out in preventing fraud risk starts from the risk assessment made by the internal auditor so that the impvolvement of the audit in assessing risk and handling the findings that occur can be resolved and provide recommendations related parties to the risk found. The reaserch method used is a qualitative descriptive method with a phenomenological approach in PD.BPR Bank Salatiga. Risk analysis mapping will be synchronized with possible events that have occurred so that the role of the internal auditors is known in assessing and resolving the risks that accur. From the risk analysis and findings, it was found that the role of the internal auditor in assessing and resolving the risks that occurred was limited to those who handled when the problems that occurred could not be resolved by the parties concerned. Internal control carried out by the bank in assessing the risks that might occur can be said to be quite good in assessing emerging risks and overcoming the risks that arise can be resolved.

Keyword : internal control, customer fund raising, fraud risk assessment 


\section{PENDAHULUAN}

PD.BPR Bank Salatiga merupakan bank lokal yang berada dibawah pengelolaan pemerintah kota Salatiga. Dalam melaksanakan kegiatan operasional perbankan PD.BPR Bank Salatiga membutuhkan adanya pengendalian internal yang berperan sebagai pengendali dari adanya risiko fraud. Pengendalian yang dilakukan terkait dengan aktivitas operasi dari penghimpunan dana nasabah agar terhindar dari adanya risiko fraud. Pada tahun 2018 PD.BPR Bank Salatiga mengalami kasus fraud yang dilakukan oleh salah seorang mantan karyawan, dengan tuduhan pemalsuan bilyet deposito oleh karyawan yang bersangkutan. Dengan adanya kasus yang pernah dialami oleh PD.BPR bank Salatiga maka pengendalian internal sangatlah penting bagi kelangsungan operasi suatu organisasi, pentingnya pengendalian yang dilakukan oleh semua pihak serta pihak terkait sangat mendukung dan membantu dalam pencegahan adanya risiko fraud.

Berdasarkan kasus kecurangan yang terjadi di PD.BPR Bank Salatiga bisa dikatakan bahwa terdapat kurangnya pengendalian dari pihak-pihak terkait, disamping karakter individu pelaku fraud. Pentingnya pengendalian yang dilakukan oleh semua pihak serta pihak terkait sangat mendukung untuk proses perbaikan. Salah satu bentuk dari pengendalian dapat ditunjukkan dengan adanya pengendalian dari pihak auditor internal. Pengendalian yang dilakukan oleh auditor internal sangat diperlukan untuk organisasi yang bergerak pada organisasi profit maupun non-profit, dengan demikian risiko fraud dapat diminimalkan. Pengaruh dari adanya peran dari auditor internal terahadap risiko adanya fraud, menunjukkan bahwa peran auditor internal sangat berpengaruh positif terhadap adanya risiko fraud, sedangkan risiko fraud berkurang dengan adanya peran dari pihak auditor internal, selain dari itu risiko dari adanya fraud dipengaruhi oleh faktor eksternal (Widilestariningtyas \& Akbar, 2014).

Pengaruh dari sistem pengendalian dan penerapan good corporate governance terhadap risiko fraud menyebutkan bahwa sistem pengendalian internal akan berpengaruh negatif terhadap risiko adanya fraud, yang dapat diartikan bahwa semakin baik tingkat pengendalian internal akan mengurangi adanya risiko fraud yang terjadi dalam suatu organisasi. Disebutkan juga bahwa penerapan GCG yang baik juga akan mengurangi tingkat terjadinya risiko fraud pada organisasi. Semakin baik tingkat pengendalian yang dilakukan oleh pihak auditor internal maka akan mengurangi risiko terjadinya fraud (Saputra, 2017).

Efektivitas pengendalian internal dan kesesuaian kompensasi terhadap risiko adanya fraud menyatakan bahwa dari efektivitas pengendalian internal akan berpengaruh signifikasn negatif terhadap kecenderungan adanya risiko fraud mulai dari risiko fraud akuntansi, asimetri informasi berpengaruh signifikan positif terhadap kecenderungan kecurangan akuntansi, dan kesesuaian kompensasi akan berpengaruh signifikan negatif terhadap risiko kecurangan akuntansi (Zainal, 2013). 
Berdasarkan femomena yang terjadi pada penelitian ini akan mengkaji tentang seberapa baik pengendalian internal dalam menilai risiko yang muncul dengan konfirmasi temuan kepada pihak terkait, sehingga pemberian rekomendasi sangat dibutuhkan dalam memperbaiki kegiatan operasional. Alasan dilakukannya penelitian ini dikarenakan PD.BPR bank Salatiga pernah terlibat kasus fraud yang dilakukan oleh mantan karyawan, sehingga penelitian ini akan melihat seberapa baik pengendalian internal yang ditetapakan oleh pihak manajemen dan pihak terkait dalam penghimpunan dana nasabah.

Mengenai kasus yang pernah dialami oleh PD.BPR Bank Salatiga yang mengakibatkan pihak bank mengalami penurunan kepercayaan dari masyarakat maka pengendalian internal sangat dibutuhkan terlebih pihak bank dan pihak terkait agar tidak terjadi kasus yang dapat menurunkan kepercayaan masyarakat. Pengendalian pada setiap aktivitas operasi penghimpunan dana nasabah sangatlah penting dikarenakan untuk meyakinkan para nasabah bahwa pihak bank telah mengelola dana dengan sangat baik, serta efektivitas dari pengendalian semua pihak sangatlah dibutuhkan.

Pengendalian yang dilakukan tidak hanya dilakukan oleh pihak auditor internal, pihak-pihak terkait juga diperlukan dalam melakukan pengendalian dan penilaian dari risiko terjadinya fraud sehingga risiko fraud dapat diminimalkan. Keterlibatan pihak-pihak terkait juga sangatlah mendukung dalam pemberian rekomendasi yang baik untuk mengurangi risiko dari setiap aktivitas penghimpunan dana nasabah.

Peran pengendalian internal dalam penghimpunan dana nasabah sangatlah penting terlebih lagi dalam proses penghimpunan dana nasabah yang memiliki kecenderungan adanya risiko tindakan fraud. Dengan adanya risiko fraud yang ada maka dibuatlah analisis risiko dari setiap aktivitas yang dilakukan dalam penghimpunan dana nasabah. Dari analisis yang telah dipetakan maka dibuatlah analisis risiko yang mungkin saja terjadi pada proses penghimpunan dana nasabah. Dari analisis risiko yang telah dipetakan maka didapatlah temuan yang mungkin saja pernah terjadi dalam proses operasional di PD.BPR Bank Salatiga. Dengan demikian penelitian ini akan melihat seberapa baik pengendalian internal dalam menilai risiko yang muncul dari setiap akivitas penghimpunan dana nasabah yang dilakukan di PD.BPR Bank Salatiga.

\section{KAJIAN PUSTAKA}

\section{A. Fraud}

Fraud merupakan tindakan kekeliruan atau kesalahan yang dibuat secara sengaja oleh seseorang atau sekumpulan orang yang mengetahui bahwa tindakan tersebut akan mengakibatkan kerugian untuk organisasi ataupun individu (Kusumawardhani, 2012). Sedangkan menurut (Arens, Elder, \& Beasly, 2008) menyebutkan bahwa fraud terjadi ketika terdapat tindakan salah saji yang direncanakan oleh seseorang dan pelaku mengetahui bahwa hal yang dilakukan merupakan tindakan yang tidak benar, untuk mencapai tujuan tertentu yang mendasari tindakan fraud. 
Faktor yang memperngaruhi dilakukannya tindakan fraud atau biasa disebut dengan fraud triangle, faktor-faktor tersebut adalah:

1. Tekanan (pressure), merupakan tindakan yang disebabkan oleh suatu kebutuhan pribadi yang mengakibatkan dilakukannya tindakan fraud, penyebab dari tindakan ini berupa tuntutan gaya hidup, ekonomi, yang mengakibatkan seseorang melakukan tindakan fraud.

2. Kesempatan (opportunity), yaitu tindakan yang terjadi ketika pengendalian internal disuatu organisasi lemah, kurangnya pengawasan, dan adanya tindakan penyalahgunaan wewenang, dalam faktor ini penerapan struktur organisasi yang baik akan membantu organisasi dalam mencegah adanya tindakan fraud.

3. Rasionalization, merupakan nilai-nilai etis yang diterapkan pada suatu organisasi, rasionalitas dalam fraud triangle sulit diidentifikasi atau diukur karena penilaian bisa dilakukan dengan adanya opini dari audior, atau pada saat siklus pergantian auditor.

Berikut merupakan gambar dari fraud triangle menurut Arens (2008) :

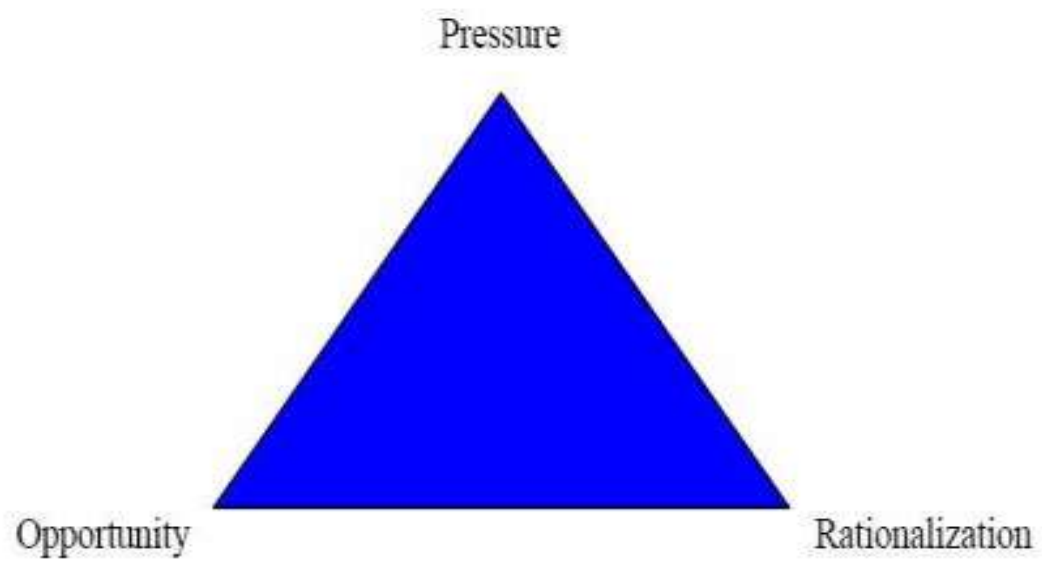

Sumber : (Arens et al., 2008)

\section{Gambar 1}

\section{Fraud triangle}

Jenis fraud menurut (ACFE Indonesia, 2016) adalah :

1. Penyimpangan atas aset (asset misappropriation) merupakan penyalahgunaan aset yang dimiliki suatu organisasi atau pihak lain;

2. Pernyataan palsu (fraudulent financial statement) tindakan melalui rekayasa laporan keuangan untuk mendapatkan keuntungan; 
3. Korupsi (corruption) merupakan tindakan mengambil harta kekayaan aset perusahaan dengan melibatkan orang-orang yang berkepentingan. Di Indoesia tindakan fraud paling banyak adalah tindakan korupsi dilihat dari hasil survai pada tahun 2016.

Berikut merupakan grafik tindakan fraud yang sering terjadi di Indonesia:

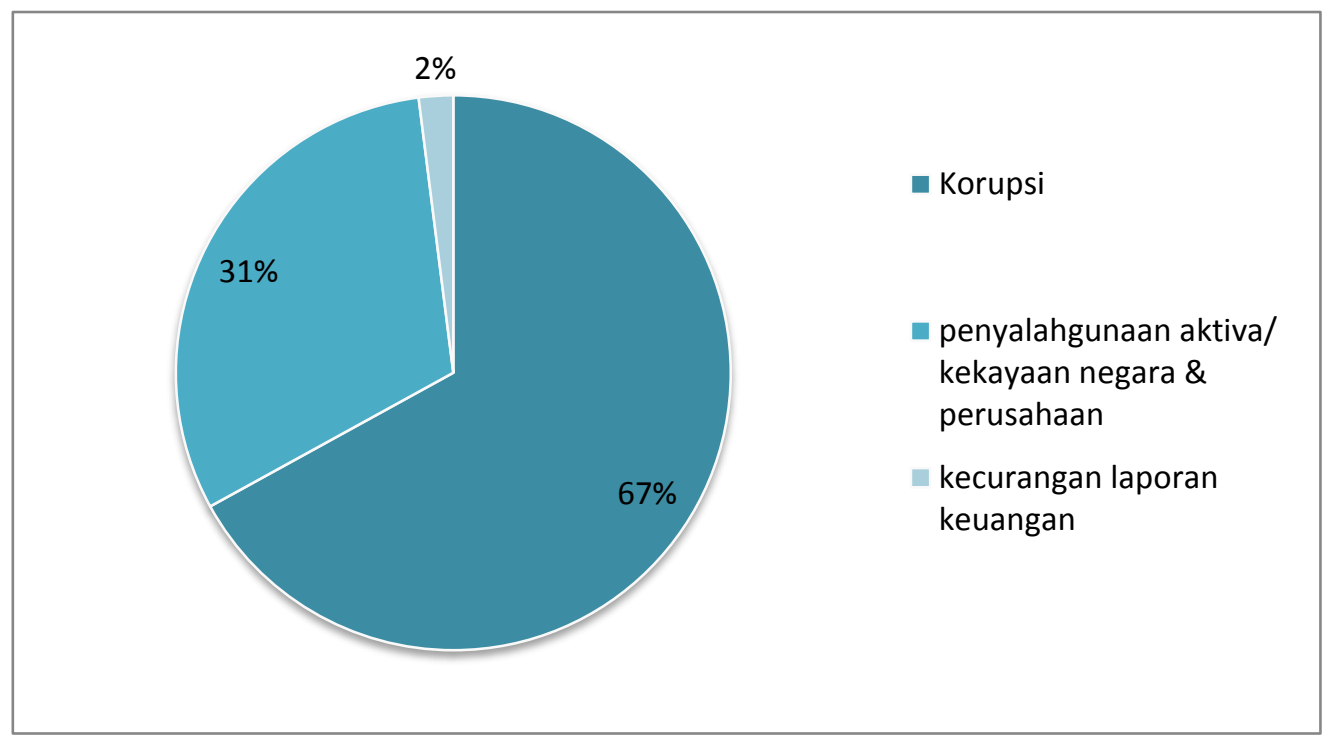

Sumber : (ACFE Indonesia, 2016)

\section{Gambar 2}

\section{Tingkat fraud di Indonesia}

\section{B. Pengendalian Internal}

Aktivitas operasi yang dilakukan untuk setiap kegiatan operasi bisnis membutuhkan adanya pengendalian yang dapat dilakukan oleh semua pihak mulai dari pihak direksi, manajemen, pimpinan perusahaan serta seluruh karyawan yang terlibat dalam suatu kegiatan operasi perusahaan. Pengendalian internal dapat dilihat dari SOP yang digunakan perusahaan dalam menjalankan aktivitas bisnisnya

Tujuan dilakukannya pengendalian internal untuk organisasi adalah :

1. Menjaga kekayaan aset suatu organisasi

2. Sebagai bahan pemeriksaan dari data akuntansi

3. Menjadikan aktivitas operasi menjadi efektif

4. Menjadikan kebijakan manajemen untuk dipatuhi (Staff Gunadarma, 2017)

Penerapan manajemen risiko dan sistem pengendalian internal yang dilakuakan untuk proses operasional di PD.BPR Bank Salatiga dilihat dari laporan tata kelola PD.BPR Bank Salatiga pada tahun 2017 adalah sebagi berikut : 
1. Pengawas aktif dewan pengawas dan direksi, pada proses pengawasan ini yang terlibat dalam melakukan pengawasan adalah dewan pengawas yang berkewajiban untuk melakukan penilaian secara berkala serta pemberian rekomendasi terhadap risiko yang muncul dan penerapan manajemen risiko dalam menjalankan kewajiban sebagai dewan pengawas yang bisa dibantu oleh pihak auditor internal di PD.BPR Bank Salatiga. Selanjutnya dewan pengawas melakukan peran aktif dalam melakukan pengawasan dari penerapan manajemen risiko yang dilakukan oleh pihak direksi, pengawasan yang dilakukan terkait dengan menyetujui dan mengevaluasi kebijakan manajemen risiko dan mengevaluasi pertanggung jawaban direksi atas pelaksanaan kebijakan manajemen risiko. Pertanggung jawaban yang dilakukan oleh pihak direksi untuk pelaksanaan kebijakan manajemen risiko dan eksporur risiko diambil oleh pihak bank secara menyeluruh, termasuk dalam mengevaluasi dan memberikan rekomendasi strategi manajemen risiko berdasarkan laporan yang disampaikan oleh unit kerja pada bagian manajemen risiko di PD.BPR bank Salatiga (PD.BPR Bank Salatiga, 2017).

Dalam melakukan kegiatan operasi bisnis suatu organisasi dibutuhkan adanya pengendalian internal, dalam hal ini dibutuhkan pedoman dalam pembuatan standar sistem pengendalian internal yang diperuntukkan untuk bank lokal maupun bank konfensional, berikut merupakan pedoman untuk pembuatan standar pengendalian internal :

1. Pengawasan yang dilakukan oleh pihak manajemen dan dilakukannya budaya pengendalian dalam setiap unit kerja.

2. Mengidentifikasi dan menilai adanya risiko yang timbul dari setiap aktivitas bisnis.

3. Sistem akuntansi, informasi dan komunikasi.

4. Kegiatan pemantauan dan tindakan koreksi dari adanya peyimpangan akttivitas bisnis (Otoritas Jasa Keuangan, 2017a)

Tujuan dari adanya pengendalian internal menurut PSA No 69 (SA 319) digolongkan menjadi beberapa tujuan antara lain :

1. Keandalan pelaporan keuangan, dalam hal ini pihak manajemen memiliki tanggung jawab hukum dan professional untuk meyakinkan bahwa informasi yang disajikan wajar sesuai dengan ketentuan prinsip pelaporan.

2. Efektivitas dan efisiensi operasi, pengendalian dalam suatu perusahaan untuk akurasi pelaporan keuangan dan nonkeuangan mengenai kegiatan operasioanl yang akan digunakan dalam pengambilan keputusan oleh para pengguna laporan keuangan.

3. Kepatuhan terhadap hukum dan peratuaran yang berlaku, perusahaan diharuskan untuk mematuhi ketentuan hukum dan peraturan terkait dengan akuntansi baik secara langsung amupun tidak langsung (Politeknik NSC Surabaya, 2017). 
Komponen pengendalian menurut COSO terdiri dari berbagai kompoen yang saling berkaitan. Komponen pengendalian internal menurut COSO antara lain :

1. Lingkungan pengendalian, komponen dari lingkungan pengendalian berupa :
a. Integritas dan nilai-nilai etis
b. Komitmen kepada kompetensi
c. Partisipasi dewan komisaris atau audit komite
d. Filosofi dan gaya operasi manajemen
e. Struktur organisasi
f. Kebijakan dan praktik sumber daya manusia

2. Penilaian risiko, dalam hal ini peran dari pihak manajemen sangat dibutuhkan dalam mengidentifikasi dan menganalisis risiko dalam prosese penyusunan laporan keuangan yang sesuai dengan GAAP.

3. Aktivitas pengendalian, dalam aktivitas pengendalian ini dibagi menjadi beberapa antara lain
a. Pemisahan tugas yang memadai
b. Otorisasi yang sesuai atas transaksi dan aktivitas
c. Dokumen dan catatan yang memadai
d. Pengendalian fisik atas aktiva dan catatan
e. Pemeriksaan kinerja secara independen

4. Informasi dan komunikasi hal ini berkaitan dengan proses pencatatan, pemprosesan dan pelaporan dari transaksi yang dilakukan suatu organisasi dalam mempertahankan akuntabilitasnya.

5. Pemantauan pengendalian yang dilakukan secara berkelanjutan oleh pihak manajemen untuk mengetahui bahwa pengendalian yang diterapkan telah sesuai dengan prosedur organisasi (Subaweh, 2017).

Dilihat dari tujuan adanya pengendalian internal untuk suatu organisasi, maka pengendalian internal dapat dibagi menjadi 3 yaitu :

1. Preventif control (pengendalian sebelum terjadinya risiko)

2. Detective control (pengendalian yang dilakukan untuk mendeteksi adanya suatu masalah mungkin saja terjadi)

3. Corrective control (pengendalian yang dilakukan untuk menyelesaikan suatu massalah)

\section{Penghimpunan dana nasabah}

Aktivitas penghimpunan dana nasabah yang digunakan pada proses bisnis di PD.BPR Bank Salatiga menggunakan strategi yang digunakan dalam proses ini diantaranya : 
1. Meningkatkan pemasaran tabungan dan deposito dengan memberikan pengenalan terhadap produk-produk yang dikelola kepada pihak masyarakat secara berkesinambungan.

2. Meningkatkan kepercayaan kepada masyarakat untuk melakukan penyimpanan dana di PD.BPR Bank Salatiga dengan senantiasa menjaga hubungan baik dengan pihak nasabah dan calon nasabah.

3. Memberikan pelayanan yang optimal kepada pihak nasabah dan calon nasabah.

4. Melaksanakan sistem jemput bola (yang dilakukan langsung kepada nasabah yang bersangkutan).

5. Meningkatkan kualitas personal agar menjadikan karyawan yang profesional.

6. Meningkatkan kemampuan untuk menggunakan sarana dan prasarana pendukung agar lebih efisien dan efektif.

7. Menganalisa dan memberikan suku bunga yang kompetitif bagi pihak nasabah tetapi tetap dapat memberikan keuntungan bagi pihak PD.BPR Bank Salatiga.

8. Melakukan inovasi produk sesuai dengan kebutuhan dan keinginan nasabah (PD.BPR Bank Salatiga, 2017).

Jenis usaha yang diperbolehkan melakukan penghimpunan dana oleh Bank Perkreditan Rakyat sesuai dengan surat edaran dari Otoritas Jasa keuangan (OJK) dalam bentuk :

1. Deposito berjangka, BPR diperbolehkan menyediakan produk simpanan yang penarikannya hanya dapat dilakukan pada kurun waktu yang telah disepakati berdasarkan perjanjian antara pihak nasabah penyimpan dengan pihak BPR.

2. Tabungan, untuk produk ini pihak BPR diperbolehkan menyediakan simpanan yang penarikan dananya hanya dapat dilakukan menurut syarat yang telah disepakati antara pihak nasabah dan pihak BPR, tetapi dana tidak dapat dicairkan melalui cek, bilyet giro, atau alat lainnya yang dipersamakan dengan produk tersebut.

3. Bentuk lainnya yang dipersamakan dengan deposito berjangka atau tabungan, bentuk lain yang dipersamakan dimaksudkan bahwa pihak BPR melakukan penghimpunan dana melalui produk simpanan yang menyerupai deposito berjangka atau tabungan melainkan bukan produk giro atau simpanan yang bisa ditarik melalui cek yang tervalidasi di BPR.

4. Pinjaman yang diterima, pihak BPR diperbolehkan menerima semua bentuk pinjaman yang diterima baik pinjaman dari pihak antar bank lain ataupun pihak ketiga yang bukan berasal dari bank dan pinjaman yang diterima merupakan pinjaman dalam negeri (Otoritas Jasa Keuangan, 2017b) 
Kegiatan penghimpunan dana dalam bentuk tabungan dan deposito menggunakan prisnsip syariah atas dasar akad Mudharabah dengan memenuhi syarat yang dikeluarkan oleh pihak bank syariah antara lain :

1. Bank bertindak sebagai pengelola dana dan pihak nasabah bertindak sebagai pemilih dari dana yang dihimpun oleh pihak bank.

2. Pengelolaan dana oleh bank dapat dilakukan sesuai dengan batasan yang ditetapkan oleh pemilih dana atau juga bisa dilakukan dengan tanpa batasan dari pemilik dana.

3. Pihak bank wajib memberikan penjelasan kepada pihak nasabah mengenai karakteristik produk yang ditawarkan, serta hak dan kewajiban pihak nasabah sesuai dengan ketetapan Bank Indonesia mengenai transparansi informasi dari produk bank.

4. Pihak bank dan nasabah wajib melakukan kesepakatan atas pembukuan dan penggunaan produk dari tabungan dan deposito.

5. Dalam akad lainnya dinyatakan bahwa syarat-syarat dan batasan tertentu yang ditentukan oleh pihak nasabah.

6. Pembagian keuntungan dinyatakan dalam bentuk nisbah yang telah disepakati antara kedua belah pihak.

7. Penarikan dana oleh nasabah hanya dapat dilakukan sesuai waktu yang telah disepakati.

8. Bank dapat membebankan kepada nasabah mengenai biaya administrasi terkait biaya yang pengelolaan rekening meliputi biaya materai, pencetakan laporan transaksi dan saldo rekening, pembukuan dan penutupan rekening.

9. Bank tidak diperbolehkan mengurangi bagian dari keuntungan pihak nasabah tanpa persetujuan dari pihak nasabah yang bersangkutan (Bank Indonesia, 2012).

Berdasarkan data penghimpunan dana yang dilakukan di PD.BPR Bank Salatiga pada tahun 2017 menyebutkan bahwa pencapaian dana penghimpunan sebesar Rp 136.860.504 dari ketetapan anggaran yang diperkirakan pada awal tahun sebesar Rp149.702.552 sehingga pencapaian penghimpunan dana di PD.BPR Bank Salatiga hanya sebesar 91,42\% pada tahun 2017 (PD.BPR Bank Salatiga, 2017).

\section{METODA PENELITIAN}

Metoda penelitian yang digunakan dalam penelitian ini menggunakan metode deskriptif kualitatif dengan pendekatan fenomenologi yang diartikan bahwa penelitian ini memaparkan suatu kejadian yang terjadi pada objek penelitian yang selanjutnya dikaji untuk memperoleh informasi dari adanya fenomena yang terjadi pada objek penelitian, dengan menggunakan teknik wawancara dan dokumentasi secara langsung pada objek penelitian. Wawancara dilakukan kepada pihak auditor internal, kepala sub bagian Keuangan, kepala bagian operasional yang ada di PD.BPR Bank Salatiga. Teknik analisis data yang digunakan adalah reduksi data yaitu peneliti mengkaji fenomena yang terjadi pada objek 
(online)

Vol 4, No 2 (2019) ; p. ; http://e-journal.stie-aub.ac.id/index.php/probank

penelitian dengan melakukan pendekatan pengumpulan data melalui wawancara pada narasumber yang bersangkutan. Berikunya dilakukan trianggulasi data dimana data yang telah diperoleh dicocokkan dengan standar pengendalian internal yang ditetapkan di PD.BPR Bank Salatiga. Selanjutnya data yang diperoleh disajikan berupa informasi yang didapat dari objek penelitian kemudian dijadikan pedoman untuk penarikan kesimpulan. Tahap terakhir adalah penarikan kesimpulan dalam tahap ini hasil wawancara yang didapat pada objek penelitian akan disimpulkan dengan mengacu pada pengendalian internal yang ditetapkan pada proses penghimpunan dana nasabah di PD.BPR Bank Salatiga.

\section{HASIL DAN PEMBAHASAN}

\section{A. Gambaran Umum PD.BPR Bank Salatiga}

PD.BPR Bank Salatiga merupakan lembaga keuangan yang bergerak dibidang perbankan, dikelola oleh pemerintah kota Salatiga sebagai pelengkap otonomi daerah pada bidang keuangan yang bergerak di sektor bank perkreditan rakyat sesuai dengan perundang-undangan yang berlaku. PD.BPR Bank Salatiga didirikan sesuai dengan ketetapan Peraturan Daerah (perda) Kota Salatiga No.02 tahun 1995 tanggal 16 Februari 1995 kemudian diganti dengan peraturan Perda No.02 tahun 2009 tanggal 29 Juli 2009. PD.BPR Bank Salatiga memiliki landasan hukum dalam menjalankan kegiatan perbankan dengan landasan hukum operasional sebagai Bank Perkreditan Rakyat adalah SK Mentri Keuangan No.Kep 323/KM.171/1997, tentang pemberian izin usaha sebagai Bank Perkreditan Rakyat kepada perusahaan daerah bank perkreditan rakyat kota madya daerah tingkat II Salatiga. Pada awal berdirinya PD.BPR Bank Salatiga menggunakan nama PD.BPR Kota Salatiga atau biasa disebut dengan Bank Pasar. Kemudian pada tahun 2009 mengganti nama menjadi PD.BPR Bank Salatiga sesuai dengan Keputusan Pimpinan Bank Indonesia Nomor 11/4/Kep.PBI/Sm/2009 tanggal 12 Agustus 2009 tentang penetapan penggunaan Izin Usaha Perusahaan Daerah BPR Kota Salatiga menjadi Perusahaan Daerah BPR Bank Salatiga. PD.BPR Bank Salatiga melakukan kegiatan operasionalnya dengan memberdayakan potensi yang dimiliki oleh masyarakat dan akan menyalurkan kembali ke masyarakat untuk mendorong kesejahteraan masyarakat (Bank Salatiga, 2008a).

Adapun visi yang ditetapkan di PD.BPR Bank Salatiga dalam menjalankan usaha perbankan yaitu : menjadikan PD.BPR bank Salatiga sebagai lembaga keuangan yang terpercaya, dengan selalu mengutamakan pelayanan terbaik sebagai perwujudan PD.BPR Bank Salatiga menjadi "Mitra Usaha Sejati Nasabah”. Sedangkan misi yang diterapkan di PD.BPR Bank Salatiga yaitu :

1. Menghimpun dana dari nasabah.

2. Mengembangkan usaha bagi pedagang kecil dan menengah serta melakukan pembinaan kepada debitur pengelola modal kerja. 
ProBank : Jurnal Ekonomi Dan Perbankan

ISSN : 2579-5597

(online)

Vol 4, No 2 (2019) ; p. ; http://e-journal.stie-aub.ac.id/index.php/probank ISSN : 2252-7885 (cetak)

3. Memberikan kontribusi pembangunan Kota Salatiga dengan menjadi sumber Pendapatan Asli

Daerah yang diandalkan.

4. Membantu perkembangan ekonomi di Salatiga dan sekitarnya (Bank Salatiga, 2008b)

Struktur tata kelola yang diterapkan di PD.BPR bank Salatiga adalah sebagai berikut :

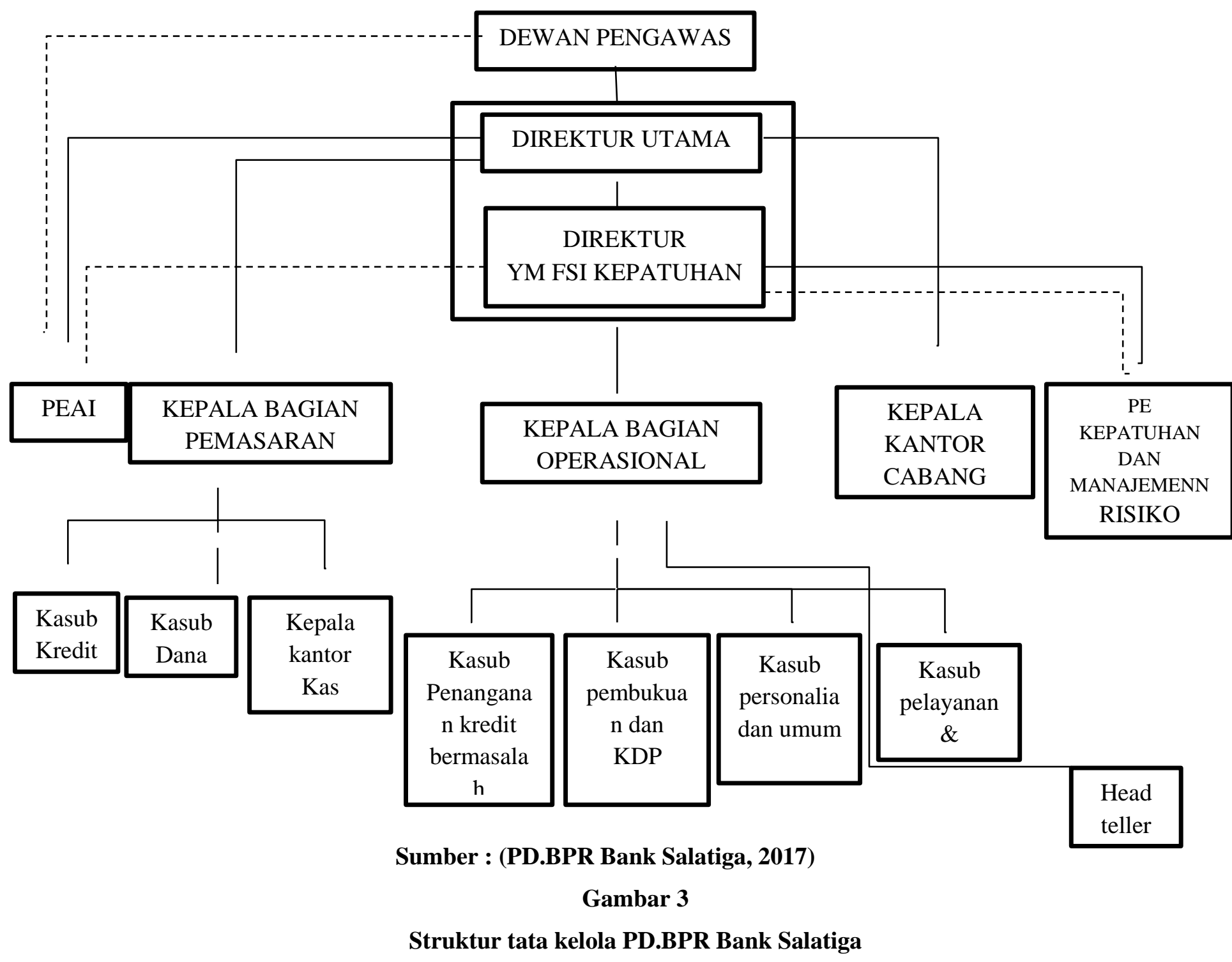

\section{B. Produk yang Ditawarkan di PD.BPR Bank Salatiga}

Produk yang ditawarkan oleh PD.BPR Bank Salatiga dalam penghimpunan dana nasabah terdiri dari berbagai produk mulai dari Tabungan, Deposito, dan Kredit. Berikut ini jenis produk yang ditawarkan oleh pihak PD.BPR Bank Salatiga : 
1. Tabungan, produk ini merupakan produk yang relatif banyak peminatnya dan PD.BPR Bank Salatiga juga menawarkan bunga untuk produk ini cukup tinggi, dana yang relatif lebih murah, dihimpun dari berbagai kelompok masyarakat umum, pelajar, pedagang. Dalam menawarkan produk ini PD.BPR Bank Salatiga memberikan beberapa jenis produk tabungan yang bisa dipilih oleh nasabah sesuai dengan kebutuhannya antara lain :

a. Tabungan Masa Depan (Tamasdep), produk ini merupakan tabungan yang bersifat fleksibel, dapat diambil sewaktu-waktu pada jam kerja di PD.BPR Bank Salatiga, dengan menawarkan suku bunga sebesar 3\% per tahun (suku bunga mengikuti indeks suku bunga bank).

b. Tabungan wajib, produk ini diperuntukkan kepada nasabah yang memiliki kredit di PD.BPR Bank Salatiga, produk ini hanya bisa dicairkan ketika nasabah telah melakukan pelunasan kredit, tingkat suku bunga yang ditetapkan untuk produk ini sebesar $2 \%$ pertahun.

c. Tabungan Teladan, produk ini diluncurkan oleh pihak bank dengan menggalakkan gemar menabung sejak dini dengan sasaran para pelajar sebagai simpanan persiapan biaya pendidikan ke jenjang berikutnya, tabungan ini tidak bisa diambil sewaktu-waktu dikarenakan produk ini menawarkan kepastian masa depan, suku bunga yang ditetapkan oleh pihak bank untuk produk ini adalah $5 \%$ per tahun.

d. Tabungan Simpanan Pelajar (Tabungan Simpel), produk ini ditawarkan kepada para pelajar dengan bantuan sekolah sebagai pengelola dana dan nantinya akan disetorkan ke bank, untuk tabungang ini diperuntukkan untuk pelajar yanh berumur dibawah 17 tahun mulai dari PAUD, TK, SD, SMP, SMA untuk nama pemegang dari produk ini atas nama siswa yang bersangkutan, suku bunga yang ditetapkan unntuk produk ini $1 \%$ per tahun.

e. Tabungan Sekolah, pada produk ini pihak bank akan melakukan kontrak dengan sekolahsekolah untuk menjadikan menabung adalah hal yang wajib dilakukan oleh pelajar, untuk pengelolaannya biasanya dilakukan oleh pihak bendahara dengan rekening atas nama sekolah tingkat suku bunga yang ditawarkan untuk produk ini adalah 3\% per tahun.

2. Deposito berjangka, produk ini merupakan simpanan pihak ketiga kepada PD.BPR Bank Salatiga dengan kesepakatan bahwa penarikan tidak bisa dilakukan sewaktu-waktu melainkan pengambilan dana hanya bisa dilakukan sesuai dengan waktu yang telah disepakati antara pihak nasabah dengan pihak bank. dibandingkan dengan produk tabungan produk depostio bisa dikatakan produk cukup tinggi nilainya, sehingga untuk pengelolaan dana harus dilakukan secara baik untuk menghindari risiko dari fraud dengan pengelolaan yang baik maka kepercayaan masyarakat akan produk ini semakin baik. deposito yang ditawarkan untuk nasabah dari PD.BPR Bank Salatiga adalah deposito berjangka yaitu 1 bulan, 3 bulan, 6 bulan, dan 12 bulan. Deposan hanya diperkenankan mengambil dana sesuai dengan jangka waktu yang telah disepakati antara pihak bank dan nasabah, jika pada saat pengambilan dana tidak sesuai dengan waktu yang disepakati maka nasabah 
diharuskan menghadap pimpinan bank serta kepala bagian dan kepala sub bagian deposito pada saat penarikan dana.

3. Kredit, layanan ini ditawarkan kepada nasabah yang memiliki kekurangan dana baik untuk usaha, pengembangan bisnis, maupun kredit pegawai. Jenis layanan produk ini diharapkan memberikan dampak positif bagi industri kecil dalam pengembangan usaha yang dijalankan dengan harapan mendapatkan laba yang diinginkan. Jenis kredit yang ditawarkan oleh pihak bank antara lain :

a. Kredit umum, layanan ini ditawarkan kepada masyarakat umum yang berada di wilayah Salatiga dan sekitarnya, dikhususkan untuk golongan ekonomi lemah. Kredit ini menawarkan antara lain kredit investasi, modal kerja, dan usaha kecil menengah (UKM). Untuk jaminan peminjaman dana kredit ini nasabah memberikan jaminan sertifikat atas nama yang mengajukan kredit, BPKB, Kartu Dasar untuk Berdagang.

b. Kredit Pegawai, produk ini ditujukan kepada Aparatur Sipil Negara (ASN), POLRI, TNI, serta karyawan swasta yang memiliki spesifikasi dari pihak bank. Dengan sistem angsungan potong gaji melalui bendahara masing-masing instansi. Jaminan dari kredit pegawai ini adalah SK Terakhir, Kartu Taspen, Kartu Pegawai, Kartu Jamsostek. Jenis kredit ini memiliki tingkat suku bunga yang relatif rendah dibanding dengan Kredit Umum.

Sebelum nasabah menerima dana pinjaman dari pihak PD.BPR Bank Salatiga, tim marketing dan kasubag bagian kredit meninjau keadaaan ekonomi para nasabah sebelum nantinya dana akan dicairkan. Dan untuk kredit pegawai pihak bank akan meninjau secara langsung ke instansi terkait. Jika pengajuan kredit hanya untuk kebutuhan sehari-hari atau karna tuntutan ekonomi pihak bank tidak akan mecairkan dana yang sebelumnya telah diajukan oleh nasabah. Jika dalam proses penagihan mengalami kendala maka pihak bank akan memberikan SP (surat peringatan) kepada nasabah sampai 3x, jika dalam jangka waktu yang telah diberikan nasabah tidak dapat mengembalikan dananya maka pihak bank akan mengambil jaminan yang telah diberikan kepada pihak bank, selain itu jika nasabah mengalami tunggakan dan bisa membayar maka akan dikenakan tarif 3\% x jumlah angsuran x lama tunggakan.

\section{Aktivitas Penghimpunan Dana Nasabah di PD.BPR Bank Salatiga}

Sebagai bank layanan umum PD.BPR Bank Salatiga memberikan pelayanan kepada masyarakat sebagai nasabah guna untuk pemberdayaan pelaku ekonomi menengah kebawah serta untuk menjembatani keperluan seluruh lapisan masyarakat yang mempercayakan dana dan pinjaman kepada PD.BPR Bank Salatiga. Sebagai bank swasta yang diawasi oleh pihak pemerintah Kota Salatiga, PD.BPR Bank Salatiga memberikan pelayanan kepada nasabah melalui produk yang dikelola oleh pihak manajemen melalui layanan produk yang ditawarkan kepada nasabah baik nasabah dari kelompok usaha kecil, usaha menengah maupun usaha besar, selain dari para wirausaha PD.BPR Bank Salatiga juga melayani nasabah yaitu para pedagang, pelajar, pegawai, perorangan. Berbagai produk yang ditawarkan PD.BPR Bank Salatiga adalah tabungan, deposito, dan kredit. Dalam melakukan aktivitas penghimpunan dana, nasabah tidak perlu datang langsung 
ke PD.BPR Bank Salatiga dikarenakan PD.BPR Bank Salatiga menerapkan sistem "jemput bola" dimana dimungkinkan bahwa nasabah tidak perlu datang langsung ke bank tetapi pihak bank akan datang menemui nasabah yang akan menyetorkan dana ke pihak bank, selain jemput bola PD.BPR Bank Salatiga juga memberikan pelayanan kepada sekolah-sekolah yang telah memiliki MOU kepada bank sebagai penyimpan dana siswa yang nantinya akan dikelola oleh pihak bank, selain itu juga pihak bank juga memberikan pelayanan kepada nasabah yang datang langsung ke bank untuk memberikan dananya yang nantinya akan dikelola oleh pihak bank.

Dari aktivitas yang dilakukan oleh PD.BPR Bank Salatiga dalam penghimpunan dana nasabah pihak bank harus menjaga kepercayaan nasabah yang telah menyetorkan dana kepada pihak bank, maka pihak bank menjaminkan dana yang telah disetorkan nasabah melalui LPS (Lembaga Penjamin Simpanan), agar menghindari risiko yang tidak diinginkan maka PD.BPR Bank Salatiga menjaminkan dananya sebesar Rp 700.000.000, melebihi dari dana yang telah diasuransikan maka dana yang ada di PD.BPR Bank Salatiga harus disetorkan antar bank untuk menghindarai risiko dari pencurian, kebakaran, dan penyalahgunaan dana dari nasabah. Penyetoran dana dilakukan kepada bank antara lain Bank Danamon, Bank Mandiri, Bank Cimb Niaga, Bank Cimb Niaga Cabang Semarang, Permata Bank, Bank Jawa Tengah dan BPR lain yang memiliki kualifikasi yang telah ditetapkan oleh pihak direksi. Selain itu dana untuk kegiatan operasioanl pada hari berikutnya harus disediakan senilai Rp 200.000 .000 yang tersimpan di cash in box guna keperluan operasioanl penarikan dan penyetoran dana nasabah pada hari berikutnya.

Sebagai bank layanan umum PD.BPR Bank Salatiga juga akan melaporkan kegiatan operasionalnya kepada pihak direksi. Laporan dibuat sebagai salinan transaksi pada hari kerja melalui sistem yang ada di PD.BPR Bank Salatiga, laporan yang dibuat berupa laporan neraca dan laporan pendapatan yang diperoleh dari perhitungan penyetoran dan penarikan dana nasabah pada hari yang bersangkutan. Sebelum laporan diberikan kepada pihak direksi untuk ditandatangani serta untuk mengecek laporan yang diberikan kepala sub bagian pembukuan dan KDP dengan sistem yang ada di PD.BPR Bank Salatiga. Jika laporan yang diberikan kepada pihak direksi telah sesuai dengan yang ada di sistem maka pihak direksi akan memberikan tandatangan untuk selanjutnya disimpan oleh pihak kasubag pendapatan sebagai laporan kepada pihak OJK dan pemerintah kota Salatiga nantinya.

Aliran penghimpunan dana nasabah yang tetapkan oleh pihak PD.BPR bank Salatiga baik dari sistem jemput bola ataupun nasabah yang datang langsung ke bank untuk mnyetorakan dana maupun penarikan dana serta penyetoran kredit. Aktivitas yang dilakukan dalam penghimpunan dana di PD.BPR bank Salatiga tidak lepas dari adanya risiko yang mungkin saja bisa terjadi. Melalui analisis risiko yang mungkin saja terjadi selanjutnya dilakukan konfirmasi apakah dari analisis risiko yang dibuat pernah terjadi dan ditemukan tindakan fraud. Berikut adalah aliran aktivitas dalam proses penghimpunan dana nasabah yang dilakukan di PD.BPR bank Salatiga : 


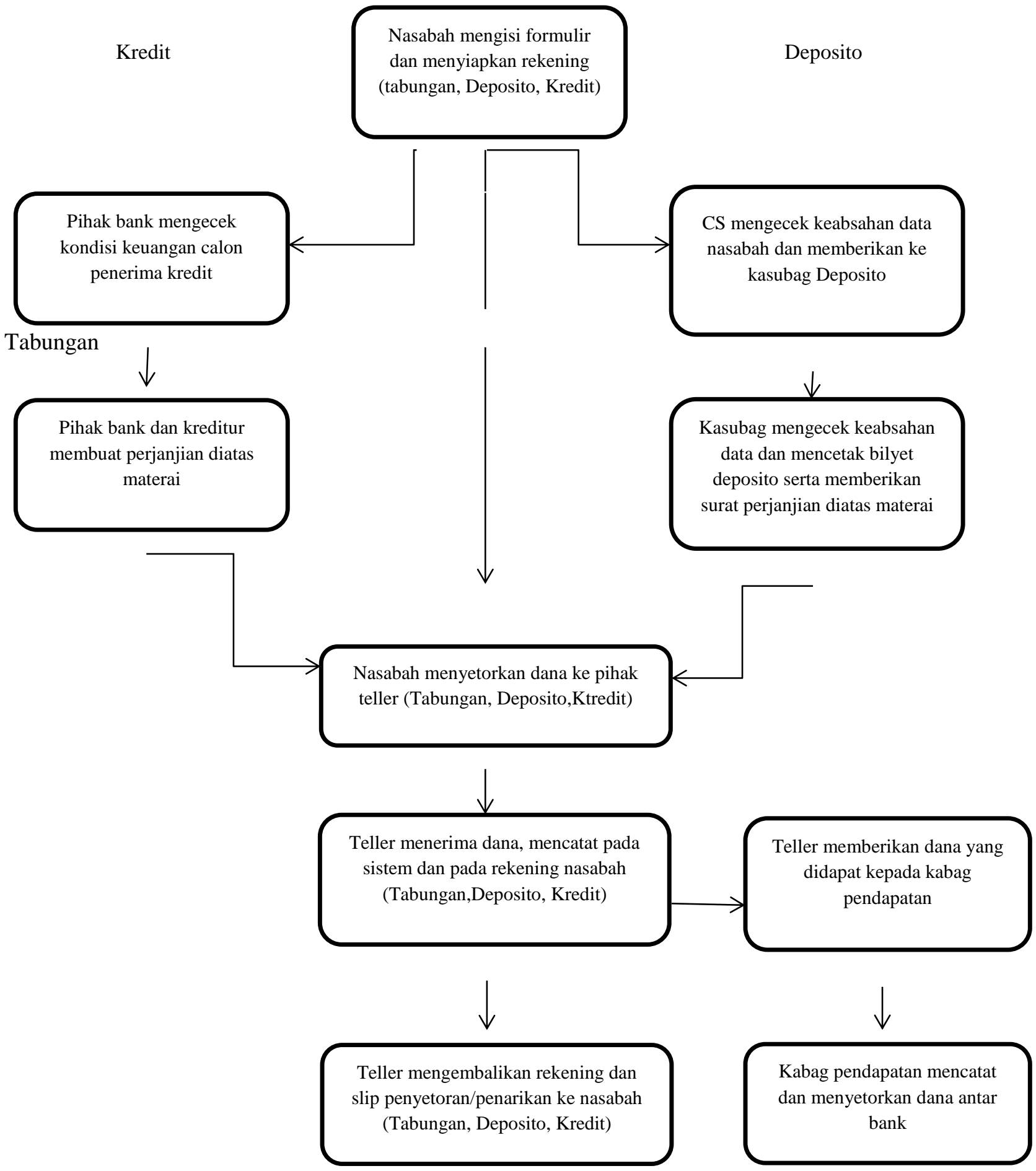

\section{Gambar 4}

\section{Aliran aktivitas proses penghimpunan dana nasabah PD.BPR Bank Salatiga}

\section{Analisis Risiko Serta Temuan yang Terjadi Pada Aktivitas Penghimpunan Dana Nasabah}

1. Nasabah menyiapkan rekening dan mengisi formulir yang disediakan PD.BPR bank Salatiga (Tabungan, Deposito, Kredit)

Pada aktivitas ini terdapat beberapa penilaian risiko yang mungkin saja terjadi yaitu : 
a. Nasabah memalsukan data diri, untuk analisis risiko ini ditemukan bahwa nasabah pernah melakukan pemalsuan data diri hal ini terjadi karena nasabah merupakan nasabah lanjut usia sehingga dalam pengisian data diri dilakukan oleh ahli waris, hal lain juga ditemukan bahwa nasabah yang tidak memiliki elektronik KTP juga cenderung memalsukan data diri mereka dikarenakan untuk pendaftaran sebagai nasabah baru harus melampirkan fotocopy elektronik KTP, ditemukan juga bahwa nasabah pasar biasanya nasabah enggan datang kekantor untuk melakukan registrasi nasabah baru sehingga jika ada kekeliruan harus melakukan kunjungan kepada nasabah yang berada di pasar untuk menkonfirmasi data diri dari nasabah.

b. Formulir yang disediakan tidak lengkap, pada analisis risiko ini ditemukan bahwa formulir yang disediakan untuk nasabah sejauh ini tidak terjadi masalah yang serius dikarenakan formulir yang disediakan untuk nasabah telah melewati quality control dari pihak manajemen dan direksi sehingga jika ada kekeliruan pada saat pencetakan bisa langsung diselesaikan dan diperbaiki sedini mungkin sebelum formulir disediakan untuk nasabah.

c. Rekening yang diberikan palsu, dalam hal ini ditemukan bahwa pemalsuan rekening pernah terjadi ketika kasus pemalsuan bilyet deposito yang pernah dilakukan oleh mantan karyawan PD.BPR Bank Salatiga, pemalsuan rekening cenderung ke produk Deposito dikarenakan produk deposito hanya terdapat satu lembar surat berharga sehingga untuk produk lain sulit dipalsukan dikarenakan terdapat transaksi yang berkelanjutan sehingga sulit untuk dipalsukan.

\section{Pihak Bank Mengecek Kondisi Keuangan Calon Penerima Kredit (Kredit)}

Analisis risiko yang mungkin saja terjadi untuk aktivitas ini adalah :

a. Nasabah memalsukan kondisi ekonomi, hal ini pernah ditemukan bahwa pihak bank baru mengetahui kondisi ekonomi dari nasabah setelah dana dicairkan.

b. Nasabah memalsukan alamat tempat tinggal, bahwa hal ini tidak pernah ditemukan pemalsuan alamat tempat tinggal dikarenakan surat permohonan kredit harus sesuai dengan data yang ada di KTP nasabah, jika nasabah pindah tempat tinggal lebih sering nasabah langsung melaporkan sehingga pihak bank bisa langsung memperbaharui data tempat tinggal nasabah.

c. Pemalsuan slip gaji untuk kredit pegawai, selama ini tidak pernah ditemukan pihak bank akan menganggap bahwa slip gaji sah jika terdapat stempel dan cap dari dinas terkait sehingga slip tersebut telah tervalidasi dari dinas yang bersangkutan.

d. Nasabah berkerja sama dengan pegawai agar dana yang diajukan segera dicairkan, hal ini tidak pernah terjadi dikarenakan pengajuan kredit harus sesuai dengan keadaan ekonomi dan kelengkapan pengajuan kredit.

\section{Pihak Bank dan Kreditur Menandatangani Surat Perjanjian Kredit (Kredit)}

Analisis risiko yang mungkin saja terjadi dalam aktivitas ini adalah :

a. Tanda tangan palsu oleh nasabah, hal ini tidak pernah terjadi sekalipun terjadi dikarenakan nasabah merupakan nasabah lansia sehingga tanda tangan dilakukan oleh ahli waris. 
b. Surat perjanjian dipalsukan oleh pihak berkepentingan, hal ini tidak pernah terjadi dikarenakan surat perjanjian akan dicetak dan dipantau oleh pihak manajemen dan direksi, serta surat perjanjian akan dicetak ketika nasabah memberikan pengajuan kredit.

c. Surat perjanjian menguntungkan salah sata pihak, hal ini tidak pernah terjadi dikarenakan pihak bank menerapkan prinsip kekeluargaan sehingga jika terjadi masalah maka akan langsung dicari titik tengah untuk mencari jalan keluar.

d. Surat perjanjian tidak ada salinan, surat perjanjian akan langsung dicetak oleh pihak bank dua rangkap sehingga nasabah bisa melakukan salinan surat perjanjian, surat perjanjian yang disimpan oleh pihak bank merupakan surat perjanjian yang bermaterai.

e. Kreditur menerima dana tidak sesuai dengan kesepakatan yang dibuat, hal ini tidak pernah terjadi karena pihak bank akan mengecek kondisi ekonomi, sehingga jika pengajuan kredit untuk gaya hidup maka pihak bank tidak akan memberikan dana kepada pihak nasabah.

4. Customer Service Mengecek Keabsahan Data Nasabah dan Memberikan Kepada Kasubag Deposito (Deposito)

Analisis risiko yang mungkin saja terjadi dalam aktivitas ini adalah :

a. Data nasabah tidak valid, pada risiko ini sering ditemukan pada nasabah yang tidak memiliki elektronik KTP, ataupun nasabah yang memberikan KTP dengan format lama.

b. Data nasabah tidak dimasukkan pada sistem yang ada, hal ini terjadi ketika nasabah datang melebihi jam kerja yang telah ditentukan oleh pihak bank, sehingga data yang diserahkan oleh nasabah akan di input pada sistem di hari berikutnya.

c. Pemalsuan data nasabah, hal ini terjadi karena kesalahan dari pihak nasabah sendiri yang salah melakukan inputing data pada formulir registrasi nasabah baru.

d. Nomor rekening nasabah dipalsukan serta rekening asli disalah gunakan pihak tertentu, hal ini pernah terjadi ketika kasus pemalsuan bilyet deposito oleh mantan karyawan PD BPR bank Salatiga.

\section{Kasubag Mengecek Keabsahan Data Serta Mencetak Bilyet Deposito dan Memberikan Surat}

\section{Perjanjian Diatas Materai (Deposito)}

Analisis risiko yang mungkin saja terjadi dalam aktivitas ini adalah :

a. Pihak bank mencetak bilyet deposito palsu, hal ini pernah terjadi pada kasus pemalsuan bilyet deposito yang dilakukan oleh mantan karyawan PD.BPR Bank Salatiga.

b. Surat perjanjian tidak sesuai dengan ketetapan bank, hal ini tidak pernah terjadi dikarenakan surat perjanjian akan dicetak melalui pengawasan dari pihak manajemen dan direksi PD.BPR Bank Salatiga.

c. Data yang dimasukkan ke sistem tidak sesuai dengan formulir yang diberikan, hal ini terjadi pada saat inputing data ke sistem pada saat bersamaan terjadi server down ataupun listrik yang 
padam, data yang diserahkan tidak sesuai dengan formulir pengajuan hal ini sering terjadi pada nasabah pasar.

d. Pemalsuan surat perjanjian antara nasabah dengan pihak bank, hal ini tidak pernah terjadi dikarenakan surat perjanjian akan dicetak ketika nasabah melakukan pengajuan deposito.

\section{Nasabah Menyerahkan Dana Kepada Pihak Teller (Tabungan, Deposito Dan Kkredit)}

Analisis risiko yang mungkin saja terjadi dalam aktivitas ini adalah :

a. Nasabah memberikan uang palsu, dalam hal ini sering terjadi pada proses operasional bank dikarenakan sebagain besar nasabah dari PD.BPR Bank Salatiga merupakan nasabah pasar, sehingga untuk proses scaning uang sulit dilakukan pada saat penghimpunan dana nasabah pasar.

b. Nasabah memberikan uang rusak, hal ini sering terjadi untuk nasabah pasar maupun nasabah yang datang langsung ke bank.

c. Jumlah uang yang disetor tidak sesuai jumlah yang tercantum pada slip penyetoran, hal ini sering terjadi dikarenakan kesalahan dari nasabah sendiri yang kurang teliti dalam perhitungan jumlah dana yang disetorkan.

d. Dana nasabah tidak disetorkan oleh pihak guru/wali kelas, hal ini menjadi tanggung jawab pihak guru wali kelas pihak bank tidak bertanggung jawab atas kesalahan yang dilakukan oleh guru wali kelas.

7. Teller Menerima Dana, Mencatat pada Sistem, dan pada Rekening Nasabah (Tabungan, Deposito, Kredit)

Analisis risiko yang mungkin saja terjadi dalam aktivitas ini adalah :

a. Pihak teller memanipulasi data penerimaan dari nasabah, hal ini jarang terjadi jikapun terjadi dikarenakan human error tanpa kesadaran diri, biasanya kesalahan salah catat nominal sebagai contoh pada slip penyetoran Rp 500.000 tetapi salah catat senilai Rp 50.000.

b. Dana yang disetorkan tidak dicatat pada sistem bank, hal ini tidak pernah terjadi dikarenakan dana yang disetorkan akan langsung dicatat pada sistem dan di catat pada rekening yang bersangkutan, jika tidak ada pencatatan disistem maka dalam rekening nasabah tidak ada pencatatan transaksi dikarenakan pencatatan pada rekening merupakan hasil output dari pencatatan pada sistem bank.

c. Pencatatan yang dilakukan tidak sesuai dengan uang yang disetorkan oleh nasabah, hal ini tidak pernah terjadi dikarenakan pencatatan akan di cocokkan dengan slip dan dana yang disetorkan.

d. Dana yang diterima tidak disetorkan kepada pihak kasubag pendapatan, hal ini tidak pernah terjadi dikarenakan pihak kasubag pendapatan akan langsung menghitung dan mengambil dana yang didapat pada hari kerja bank. 
8. Teller Mengembalikan Rekening dan Slip Penyetoran Kepada Nasabah (Tabungan, Deposito, Kredit)

Analisis risiko yang mungkin saja terjadi dalam aktivitas ini adalah :

a. Rekening yang diberikan merupakan rekening kosong, hal ini tidak pernah terjadi pada proses operasional bank.

b. Pemalsuan rekening nasabah, hal ini terjadi pada kasus pemalsuan bilyet deposito yang dilakukan oleh mantan karyawan PD.BPR Bank Salatiga.

c. Rekening tidak dikembalikan kepada nasabah (untuk sistem jemput bola), hal ini terjadi dikarenakan permintaan dari nasabah sendiri, untuk SOP pengembalian rekening nasabah harus dilakukan 1 hari setelah pencatatan transaksi pada sistem.

d. Rekening yang diberikan tidak mencatat transaksi yang dilakukan nasabah, hal ini tidak pernah terjadi karena dana dari nasabah akan langsung dihitung dicocokkan dengan slip dan langsung di input pada sistem dan rekening nasabah, secara otomatis pada saat pencatatan transaksi nasabah akan langsung tercatat pada rekening nasabah melalui hasil printout.

\section{Teller Memberikan Dana Yang Didapat Kepada Kepala Bagian Pendapatan}

Analisis risiko yang mungkin saja terjadi dalam aktivitas ini adalah :

a. Dana yang diberikan tidak sesuai dengan pendapatan yang diterima, hal ini jarang terjadi karena data pada sistem akan langsung membackup pendapatan yang diterima setiap harinya.

b. Data pendapatan pada sistem dimanipulasi, hal ini tidak pernah terjadi dikarenakan jumlah pendapatan akan langsung terjumlah nominalnya sehingga sangat sulit untuk dimanipulasi.

c. Beberapa pendapatan tidak dicatat dalam sistem, hal ini tidak pernah terjadi dikarenakan setiap transaksi nasabah yang datang akan langsug dicatat pada sistem jika tidak ada pencatatan di sistem maka juga tidak terdapat pencatatan transaksi pada rekening nasabah.

d. Laporan yang diberikan kepada bagian pendapatan tidak sesuai dengan penerimaan dana, hal ini tidak pernah terjadi karena bagian pendapatan akan langsung mencocokkan dana harian dengan pendapatan yang terdapat di sistem bank sehingga jika terjadi selisih akan langsung ditelusuri.

\section{Pihak Kapala Sub Bagian Pendapatan Menyetorkan Dana Antar Bank}

Analisis risiko yang mungkin saja terjadi dalam aktivitas ini adalah :

a. Dana yang dimiliki bank tidak disetorkan ke antar bank, hal ini jarang terjadi jikapun terjadi dikarenakan bank terkait telah tutup sehingga penyetoran akan dilakukan dihari berikutnya dan dana yang akan disetorkan langsung dikembalikan lagi ke bank dan disimpan dalam brangkas.

b. Dana yang disetorkan tidak dicatat dalam laporan neraca, hal ini tidak pernah terjadi dikarenakan bank menggunakan sistem yang secara otomatis jika terjadi transfer antar bank akan langsung tercatat pada sistem dan secara otomatis akan tercatat dan membuat laporan neraca. 
c. Dana nasabah disetorkan ke rekening pribadi, hal ini tidak pernah terjadi dikarenakan transfer antar bank akan langsung dipantau oleh pihak direksi dan manajemen, setelah dilakukan transfer juga akan langsung dicatat pada laporan neraca yang akan diserahkan kepada pihak direksi.

d. Laporan penyetoran antar bank dipalsukan, hal ini tidak pernah terjadi dikarenakan penyetoran dana juga akan dicatat pada sistem sehingga laporan neraca akan langsung tercatat, dan laporan penyetoran serta slip penyetoran akan dilampirkan dalam pelaporan yang akan diberikan kepada pihak direksi.

\section{E. Rekomendasi Atas Temuan Pada Aktivitas Penghimpunan Dana Nasabah}

Rekomendasi yang dapat diberikan untuk proses perbaikan dari analisis risiko serta temuan yang didapat pada proses aktivitas penghimpunan dana nasabah di PD.BPR Bank Salatiga adalah :

1. Aktivitas nasabah menyiapakan rekening dan mengisi formulir yang disediakan oleh pihak PD.BPR bank Salatiga, dalam aktivitas ini terdapat beberapa risiko yang ditemukan dalam proses penghimpunan dana nasabah adapun rekomendasi yang dapat diberikan untuk proses perbaikan yaitu pengecekan data diri nasabah melalui website dari dinas kependudukan dan catatan sipil (dukcapil) untuk mengetahui data diri nasabah sesui dengan yang ditetapkan oleh pihak dukcapil. Untuk nasabah yang tidak dapat datang ke kantor untuk melakukan registrasi sebaiknya melampirkan surat kuasa yang menyatakan bahwa nasabah yang bersangkutan benar-benar tidak dapat datang langsung untuk melakukan registrasi sehingga menunjuk utusan untuk melakukan registrasi. Dilakukan pembuatan nomor seri untuk produk deposito yang hanya diketahui oleh pihak manajemen dan direksi.

2. Aktivitas pihak bank mengecek kondisi keuangan calon penerima nasabah, terdapat beberapa temuan yang bersifat negatif sehingga diperlukan adanya rekomendasi yang dapat digunakan dalam memperbaiki aktivitas yaitu berupa pengecekan berkala, pengecekan juga melibatkan pihak tetangga sehingga pihak bank akan dapat mengetahui kondisi nasabah dari tetangga. Mencocokkan data permohonan kredit dengan KTP yang dilampirkan. Perubahan alamat tempat tinggal akan langsung dilakukan pengecekan dan pembaharuan data pada sistem. Meninjau pada dinas terkait sesuai dengan pengajuan yang ada pada slip gaji pegawai.

3. Aktivitas pihak bank dan kreditur menandatangani surat perjanjian kredit dalam aktivitas ini terdapat beberapa analisis risiko yang mungkin saja bisa terjadi dari adanya risiko tersebut maka diberikanlah rekomendasi yang dapat dijadikan sebagai bahan pertimbangan untuk proses perbaikan yaitu untuk tanda tangan yang diwakilkan harus melampirkan surat kuasa serta yang diwakilkan harus diberitahukan isi dari surat perjanjian. Membuatkan salinan surat perjanjian untuk nasabah jika suatu saat nasabah kehilangan surat perjanjian. Melakukan pengecekan kondisi 
ekonomi dengan melibatkan para tetangga sehingga kehidupan nasabah akan diketahui oleh pihak bank.

4. Aktivitas customer service mengecek keabsahan data nasabah dan memberikan kepada kasubag deposito dalam aktivitas ini terdapat risiko yang mungkin ssaja terjadi dalam aktivitas ini rekomendasi yang dapat diberikan untuk proses perbaikan adalah untuk nasabah yang tidak memiliki elektronik KTP diharapkan membawa salinan kartu keluarga untuk mengetahui NIK dan NIKK serta mencocokkan data nasabah dengan data yang ada di dukcapil. Untuk nasabah yang datang melebihi jam kerja diberikan pengertian bahwa inputing data akan dilakukan pada jam kerja hari berikutnya sehingga dokumen yang diserahkan akan disimpan oleh pihak bank serta nasabah diharapkan datang pada hari berikutnya untuk proses registrasi. Memberikan pengertian kepada nasabah bahwa kesalahan yang dibuat nasabah tidak menjadi tanggung jawab oleh pihak bank, serta membantu nasabah dalam pengisian formulir registrasi nasabah baru sehingga nasabah tidak kesulitan dalam pengisian data. Pemberian nomor seri pada bilyet deposito yang dicetak serta pembuatan hologram untuk meminimalisir adanya tindakan kecurangan.

5. Aktivitas kasubag mengecek keabsahan data serta mencetak bilyet deposito dan memberikan surat perjanjian diatas materai, pada aktivitas ini terdapat temuann yang pernah terjadi dan dialami oleh pihak PD.BPR Bank Salatiga mengenai kasus pemalsuan bilyet deposito yang dilakukan oleh mantan karyawannya, rekomendasi yang dapat diberikan untuk memperbaiki proses penghimpunan dana nasabah adalah dilakukan pengawasan yang lebih intens serta pembuatan nomor seri dan hologram untuk produk deposito dan dilakukan pembuatan kode verifikasi yang hanya diketahui oleh pihak manajemen. Melakukan backup data ketika sewaktu-waktu server mengalami down ataupun listrik yang padam, untuk nasabah pasar yang yang memasukkan data tidak sesuai dengan formulir yang diberikan sebaiknya pihak marketing yang mendatangi nasabah diharapkan memastikan data pada formulir sehingga ketika ada kesalahan akan langsung dirubah sebelum data tersebut dibawa ke bank untuk dimasukkan ke sistem yang ada di bank.

6. Aktivitas nasabah menyerahkan dana kepada pihak teller, dalam hal ini terdapat beberapa analisis risiko yang mungkin saja bisa terjadi dari analisis tersebut terdapat temuan yang pernah dialami oleh pihak PD.BPR Bank Salatiga, rekomendasi yang dapat diberikan untuk memperbaiki proses penghimpunan dana nasabah adalah dalam penyetoran dana nasabah pasar sebaiknya pihak marketing melakukan pengecekan keaslian uang ditempat jika terjadi kejanggalan uang bisa langsung dikembalikan kepada nasabah yang bersangkutan. Untuk pemberian uang rusak sebaiknya pihak bank tetap menerima dana nasabah yang kemudaian akan ditukar maupun disetorkan ke bank konfensional selanjutnya akan diserahkan ke Bank Indoneesia. Melakukan pengecekan dan perhitungan dana kembali di bagian teller dan memberikan pemberitahuan kepada nasabah bahwa uang akan dihitung ulang sehingga nasabah tidak diperkenankan untuk menginggalkan bagian teller. Untuk pihak guru wali yang tidak menyetorkan dana nasabah 
dilakukan kerja sama antara wali murid jika dalam penyetoran tidak dicatat dalam sistem dianjurkan untuk konsultasi kepada pihak guru wali kelas yang bertanggung jawab pada rekening siswa.

7. Aktivitas teller mmenerima dana, mencatat pada sistem dan pada rekening nasabah, pada aktivitas ini terdapat beberapa risiko yang mungkin saja bisa terjadi dalam proses penghimpunan dana nasabah rekomendasi yang dapat diberikan untuk perbaikan dan mempertahankan temuan positif adalah mempertahankan pengawasan dan pengendalian untuk aktivitas ini.

8. Aktivitas teller mengembalikan rekening dan slip penyetoran kepada nasabah, dalam aktivitas ini terdapat beberapa risiko yang mungkin ssaja muncul pada aktivitas penghimpunan dana nasabah, dari temuan yang didapat dalam proses aktivitas diberikanlah rekomendasi yang diberikan untuk memperbaiki aktivitas yaitu pengawasan untuk pencetakan seluruh produk harus diawasi dan di pantau oleh pihak manajemen serta pemberian nomor seri dan hologram untuk menghindari pemalsuan produk PD.BPR Bank Salatiga. Memberikan pemberitahuan kepada nasabah bahwa SOP yang ditetapkan pihak bank rekening nasabah harus dikembalikan sesui dengan ketetapan dari pihak bank.

9. Aktivitas teller memberikan dana yang didapat kepada kepala bagian pendapatan, dalam aktivitas ini terdapat temuan yang terjadi pada proses penghimpunan dana nasabah dalam hal ini temuan yang didapat berupa temuan positif segingga rekomendasi yang diberikan adalah peningkatan pegawasan serta mempertahankan pengendalian yang telah berjalan agar tidak terjadi risiko fraud, serta pembuatan hak akses dalam sistem yang ditetapkan oleh pihak bank.

10. Aktivitas pihak kepala sub bagian pendapatan menyetorkan dana antar bank, dalam aktivitas ini terdapat temuan yang terjadi pada proses penghimpunan dana nasabah, dalam hal ini temuan yang didapatkan berupa temuan bersifat positif sehingga rekomendasi yang dapat diberikan adalah mempertahankan pengawasan dan pengendalian yang telah diterapkan di PD.BPR Bank Salatiga.

Rekomendasi yang diberikan terhadap temuan yang didapatkan pada proses penelitian ini bersifat situasional, sehingga pada penerapan rekomendasi didasarkan pada kejadian yang dialami dan terjadi di objek penelitian.

\section{PENUTUP}

\section{Kesimpulan}

Berdasarkan penelitian dan pembahasan dapat disimpulkan bahwa

1. Pengendalian yang dilakukan oleh auditor internal hanya sebatas menangani masalah yang telah terjadi untuk menilai risiko yang mungkin saja terjadi sangat kurang dikarenakan pada saat kegiatan wawancara berlangsung kepada pihak auditor internal, auditor internal menyarankan 
untuk langsung datang ke bagian operasioanl yang lebih mengetahui analisis risiko yang telah dipetakan oleh penulis, sehingga untuk temuan dari analisis risiko yang telah dipetakan lebih banyak ditemukan dan diselesaikan oleh pihak operasional, untuk risiko yang yang tidak dapat diselesaikan oleh pihak operasional maka baru akan dilimpahkan kepada auditor internal.

2. Prosedur penilaian risiko untuk setiap aktivitas pneghimpunan dana nasabah dikatakan belum baik dikarenakan setiap risiko yang muncul akan langsung ditangani pada bagian operasional sedangkan untuk pengawasan dan penyelesaian juga dilakukan oleh pihak operasional, sehingga bisa dikatakan bahwa pengendalian yang dilakukan oleh pihak auditor internal bisa dikatakan belum maksimal.

3. Sejauh ini pengendalian yang ditetapkan oleh pihak PD.BPR Bank Salatiga bisa dikatakan cukup baik dalam menangani berbagai risiko yang sering muncul, sehingga dalam menangani risiko yang muncul sangat baik.

4. Dari analisis risiko yang dipetakan oleh peneliti dengan dibandingkan dengan temuan yang pernah terjadi pada proses operasioanl bank, ditemukan bahwa dari beberapa analisis risiko hanya sebagian kecil pernah terjadi pada proses operasional di PD.BPR Bank Salatiga.

5. Sejauh ini tahap recovery dari masalah yang pernah terjadi pada proses operasional PD.BPR Bank Salatiga dikatakan bahwa pengendalian yang ditetapkan setelah kejadian pemalsuan bilyet deposito yang melibatkan mantan karyawan PD.BPR bank Salatiga semakin meningkat dan lebih baik dalam menilai risiko dan pengawasan yang ada semakin meningkat kearah yang lebih baik sehingga kepercayaan masyarakat terhadap PD.BPR Bank Salatiga tetap terjaga.

6. Keterbatasan dalam penelitian ini yaitu pada proses penelitian auditor internal yang menjadi sumber informasi yang utama mengundurkan diri dari pekerjaan sebagai auditor internal di PD.BPR Bank Salatiga, sehingga peneliti tidak dapat memperoleh informasi untuk memperkuat penelitian.

\section{Saran}

Saran yang dapat diberikan untuk penelitian selanjutnya dan untuk PD.BPR Bank Salatiga adalah :

1. Untuk penelitian selanjutnya diharapkan memperluas cakupan aktivitas operasi bisnis sehingga analisis risiko yang bisa saja terjadi pada setiap aktivitas semakin beragam, dengan begitu maka akan didapatkan berbagai temuan yang bisa saja terjadi serta penanggulangan dan peran dari pihak auditor internal maupun pihak terkait.

2. Untuk pengembangan penelitian dari penulisan ini diharapkan agar dapat memrbandingkan antara bank konfensional dengan bank lokal terkait dengan pengendalian internal di berbagai aktivitas penghimpunan dana nasabah. 
3. Penelitian selanjutnya diharapkan penulis meneliti tentang penyaluran dana nasabah yang dilakukan di PD.BPR Bank Salatiga, sehingga untuk risiko yang muncul dari aktivitas penyeluran dana dapat diketahui serta dalam penelitian selanjutnya dapat melihat dari penghimpunan dan penyaluran dana di PD.BPR Bank Salatiga apakah berjalan secara efektif dan efisien sesuai dengan perundang undangan yang berlaku.

4. Untuk penelitian yang dilakukan di PD.BPR Bank Salatiga diharapkan untuk mengakaji tentang efektifitas dari adanya auditor internal untuk melihat kesesuaian antara kode etik dan penerapan kerja auditor.

5. Untuk menciptakan pengendalian dan pengawasan yang lebih baik diharapkan pihak auditor internal membuat matriks penilaian risiko sehingga jika terjadi masalah akan dapat segera terselesaikan dengan baik

\section{DAFTAR PUSTAKA}

ACFE Indonesia. (2016). Survai Fraud Indonesia.

Arens, A. A., Elder, R. J., \& Beasly, M. S. (2008). Auditing dan Jasa Assurance Pendekatan Terintegrasi. In ERLANGGA (1st ed.). ERLANGGA.

Bank Indonesia. (2012). Liabilitas dan Modal Pelaksanaan Prinsip Syariah dalam Kegiatan Penghimpunan Dana dan Penyaluran Dana serta Pelayanan Jasa Bank Syariah, Produk Bank Syariah dan Unit Usaha Syariah.

Bank Salatiga. (2008a). Sejarah PD.BPR Bank Salatiga. Retrieved from http://www.banksalatiga.com/2017/09/30/sejarah-perusahaan/

Bank Salatiga. (2008b). VISI MISI PD.BPR Bank Salatiga. Retrieved from http://www.banksalatiga.com/2017/09/30/visi-dan-misi-perusahaan/

Kusumawardhani, P. (2012). Deteksi Financial Statement Fraud dengan Analisis Fraud Triangle pada Perusahaan Perbankan yang Terdaftar BEI.

Otoritas Jasa Keuangan. (2017a). Pedoman Pengendalian Internal OJK, 2-3.

Otoritas Jasa Keuangan. (2017b). Salinan Surat Edaran Otoritas Jasa Keuangan.

PD.BPR Bank Salatiga. (2017). Laporan Tata Kelola PD BPR Bank Salatiga Tahun 2017, (5), 1-51.

Politeknik NSC Surabaya. (2017). Pengertian Pengendalian Intern, 1-18. Retrieved from http://pdf.nsc.ac.id/6-pengendalian intern-20151117.pdf 
Saputra, A. (2017). Pengaruh Sistem Internal, Kontrol, Audit Internal dan Penerapan Good Corporate Governance Terhadap Kecurangan ( FRAUD ) Perbankan ( Studi Kasus pada Bank Syariah Anak Perusahaan BUMN di Medan ), 1.

Staff Gunadarma. (2017). Sistem Pengendalian Intern.

Subaweh, I. (2017). Pengertian Pengendalian Internal.

Widilestariningtyas, O., \& Akbar, T. A. (2014). Pengaruh Audit Internal Terhadap Risiko Fraud ( Survai Pada PT . BRI di Wilayah Bandung ), VI(1).

Zainal, R. (2013). Pengaruh Efektivitas Pengendalian Internal, Asimetri Informasi dan Kesesuaian Kompensasi Terhadap Kecenderungan Kecurangan Akuntansi (Fraud). 